policy of the Southern and Eastern States could never commend itself to those who have learnt lessons from the past. Indeed, one might well defend Urban VIII. in re Galileo-as Huxley did-and condemn Tennessee, Oklahoma and Co. in the present issue. Of course, the teaching of advanced evolutionism lends itself fairly readily to being made the vehicle for communicating an anti-religious bias. To endeavour to inoculate unformed minds with such a prejudice would evidently be taking an unfair advantage. Indeed, such conduct is opposed to science as well as to morality. It is out of place, therefore, even with mature pupils; both science and religion should confine themselves to their respective provinces.

If any one wishes to combat any doctrine which he regards as erroneous, he should equip himself for the task from the armoury of sound knowledge. It is not for the legislature to enter the lists. Nor should the State run the risk of even appearing to repress honest inquiry.

\section{Prof. G. H. F. NutTall, Sc.D., M.D., F.R.S., Quick Professor of Biology in the University of Cambridge.}

THE leaders of thought throughout the world have for centuries been unhesitating supporters of the principle that intellectual freedom should prevail in university teaching. Therefore, the opposition to the principle which we are witnessing in the United States to-day, in the form of legislation against the teaching of evolution, is of a character which must fill us with apprehension for the future of "the land of the free and the home of the brave," and of the ability of that land to continue thus to describe itself. Involuntarily we ask ourselves, "What next? Where will this end? ... if the ignorant majority can thus impede human progress towards truth." The resolution adopted by the Council of the American Association for the Advancement of Science will assuredly be approved by all competent men of science.

\section{Sir Oliver Lodge, D.Sc., F.R.S.,}

Formerly Principal of the University of Birmingham.

THE outcry against the teaching of evolution in some of the United States seems so preposterous in Great Britain that the only use we can make of it is to bethink ourselves whether we.are not doing, or wishing to do, or have not done, something of the same sort in connexion with a less established region of scientific inquiry. Actual prohibition may be difficult of accomplishment, but a refined system of boycotting, such as has begun in the United States in connexion with the doctrine and facts of evolution, can be applied with greater ease, and has already been effective in restraining recruits and silencing the utterances of some who might otherwise have been willing to testify to what they know of truth in other subjects. Had Sir William Crookes been a university professor it would have gone still harder with him than it did. Lehrfreiheit is only granted with limitations; it is tolerated so long as it does not outrage preconceived opinion and introduce discord into a pre-established harmony.

\section{Rev. S. M. BERRY, D.D., \\ Secretary, Congregational Union of England and Wales.}

ALI those who have enjoyed an education steeped in the spirit of freedom will hope that the threat to that freedom in the schools of the United States may be averted. The idea that teachers should be prohibited from teaching the doctrine of evolution because it is opposed to a certain interpretation of the Biblical account of the Creation, seems to progressive minds on this side of the Atlantic both ludicrous and preposterous. To the minds of all progressive churchmen, any such prohibition would be regarded as a set-back to religious progress and a denial of that liberty of opinion in matters of religion which it has taken centuries to win. That such a threat should come from the United States is history's latest irony.

\section{Rev. H. B. Workman, D.Litt., D.D.,}

Senator of London University, Principal of Westminster Training College.

ANY attempt to interfere with freedom in the teaching of evolution is wholly reactionary, and is bound in the long run to be prejudicial to religion. Dogmatism, whether by scientists or theologians, should give place to a greater consciousness of the vast regions of the unknown.

\title{
Truth and Doctrine in Science and Religion.
}

$\mathrm{T}$ HE vagaries of those near to us in kin are proverbially harder to understand than those of strangers, and it is equally true that it is less easy to appreciate the shibboleths of the generations immediately preceding our own than those of a remoter date. It is undoubtedly a fact that the common element in British culture and that of the United States has often served to obscure certain fundamental differences of which the occasional manifestation sometimes amazes and more often bewilders us. The tendency shown by certain State legislatures in America in their attitude towards the doctrine of evolution, which has culminated in the prosecution of a teacher in the State of Tennessee for the use of a text-book in which a reference to that doctrine was included, is indicative of a public opinion of a force and character which it is difficult for us in Great Britain and in these days to appreciate.

Scientific workers on this side of the water are accustomed to meet their American colleagues on an equal footing. They expect to find among them a readiness equal to their own to accept the facts which scientific investigation may bring to light and an equal openness of mind in the discussion of the bearing of such facts upon accepted theory: It has, therefore, come with something of a shock to them to find that a movement upon which they may have looked with some feeling of amusement, and as such may not have regarded more seriously than as a passing phase, is likely to prove an obstinate barrier to intellectual progress and freedom of discussion. Those who have followed the trend of thought among the intellectual section of the general public in the United States for any length of time may not be equally surprised. They have been aware that sooner or later some such question as this was bound to arise. It is not so long ago that a well-known American novelist put before his 
public, as a living question of to-day, in the church of an American city, the problems which exercised the readers of "Robert Elsmere" when first that book was published in Great Britain nearly forty years ago.

The problem with which the more advanced section of intellectual America is now confronted is as old as the hills, or at any rate as old as man himself. Every age and every country produces its Socrates and its Galileo. Everywhere the prophets are stoned when speculation or scientific discovery comes into conflict with the emotions of the majority.

In Great Britain, it is perhaps safe to say that the cause of intellectual freedom has been won. It is not likely that we shall witness again a struggle over a purely scientific doctrine, such as that which raged around the controversies of the middle and latter half of last century. It is difficult for a generation brought up in the freer atmosphere which is a result of those fierce encounters, to enter fully into the intensity of feeling which was aroused by the theological disputes of the earlier Victorian era. The famous Gorham case and the heated discussion of questions of church government which it aroused, and the Tractarian movement, were only a prelude to the storm raised by the publication of F. D. Maurice's "Theological Essays" in 1854 , repudiating the doctrine of eternal punishment, which forced his resignation of his professorial chair at King's College, London; while the heated arguments over the archæological discoveries of Boucher de Perthes in the Somme Valley, which relegated man to a vast antiquity, merely paved the way for the tempest which followed the application of the Darwinian hypothesis to the problem of man's origin.

The recent celebrations of the centenary of Thomas Henry Huxley have served to recall the many controversial questions in the discussion of which he was a protagonist ; of these, perhaps his encounters with Wilberforce at Oxford, and with Gladstone, have remained most firmly fixed in public memory. To his fearless championship of the doctrine of evolution in the stormy years of the 'sixties of last century, following on the publication of "The Origin of Species," is due as much as to any the victory of freedom for scientific inquiry into, and speculation on, the great problems of the origin and development of the forms of life. His conception of the sanctity of truth, and his fearless acceptance of facts whatever might be their bearing upon dogma in any field of inquiry, remain the creed of the scientific investigator of to-day. But that it is generally recognised as right to hold that creed is due to those who bore the heat and burden of that day-Darwin, Huxley, Tyndall and others of their time. Much must be attributed to the force of personality of those who participated in these controversies, and perhaps as much to the writings of one who took no active part in them himself, namely, Herbert Spencer. Spencer's writings, and particularly his sociological writings, by their application of the biological conception and the evolutionary point of view to the study of man as a social being, did much to secure acceptance for the doctrine of evolution among the intellectual public.

Further, in anthropology the work of Tylor in the comparative study of the beliefs of man demonstrated that behind the great religions of the world there lay a long process of growth which could be traced back stage by stage to the primitive animism of the savage, a work which has been extended and confirmed by the labours of Sir James Frazer. At the same time, the studies of the archæologists, in conjunction with the geologists, were extending to more and more remote periods of time, and to an increasingly primitive stage, the evidence for man's existence, in the shape of the primitive stone implements which marked his early efforts to control and shape his environment to his needs. Concurrently, the critical study of the Bible-the Higher Criticism-was demonstrating the composite character of its parts, while its sources-notably the story of the Creation deciphered by Smith from the cuneiform inscriptions-were being derived from other than Jewish sources.

It would scarcely be worth while to recapitulate these familiar facts if it were not to recall that, immediately following upon the formulation of Darwin's theories and their discussion, there was a convergence of evidence bearing upon the origin and history of man and on his beliefs, some of it derived from an extended application of the evolutionary method of study, which by superseding the traditional static view, tended to facilitate if not the acceptance at any rate the preservation of an open mind towards the central problem.

To the scientific mind, perhaps it is a temptation to over-estimate the extent to which the cogency of an argument has appealed to the general public. The freedom in discussion of matters of the intellect which has been won in Great Britain must perhaps in part be attributed to the national temperament. The key may perhaps be found in the writings of Herbert Spencer, the apostle of the individualism which is the most marked characteristic of the Englishman. The appeal to authority which is the negation of the intellectual freedom postulated by scientific inquiry is by tradition and training alien to the British temperament. The nineteenth century in Great Britain was a time of intellectual ferment in the political as well as the scientific world, but in both cases it was the culmination of a movement which had been in being for centuries. The demand for "Civil and Religious Liberty," which was the war-cry of one of the great political parties of the day, was merely the traditional spirit which gave rise to the Reformation, to nonconformity and to the reforms of the Philosophical Radicals at the beginning of the nineteenth century.

It may be that it was by good fortune that the battle of the Darwinian hypothesis and its extension to the evolutionary theory was fought on favourable ground. That for us of to-day is a matter of history. But it lays upon those who hold the torch to hand it on undimmed and to watch jealously that, in changing conditions, no change can affect the unity of free and unfettered discussion in all matters that appertain to the pursuit of knowledge. In these days, when science is universal and co-operation in scientific research transcends national boundaries, it is impossible that what affects a part should not affect the whole. The whole scientific world will therefore watch with no little interest and anxiety the result of a trial which may by its results affect the intellectual progress of one of the great nations of the world. Not only may it stunt the intellectual growth of generations : it may also debar her from all participation in the advancement of one of the most important of the branches of knowledge. 